\title{
SINDROMA VERTIGO SENTRAL SEBAGAI MANIFESTASI KLINIS STROKE VERTEBROBASILAR PADA PASIEN PEMFIGUS VULGARIS
}

\author{
Ratih Kusumastuti ${ }^{1}$, Sri Sutarni ${ }^{2}$ \\ ${ }^{1}$ Residen Neurologi Fakultas Kedokteran, Universitas Gadjah Mada/ RSUP Dr. \\ Sardjito Yogyakarta \\ ${ }^{2}$ Bagian Neurologi Fakultas Kedokteran, Universitas Gadjah Mada/ RSUP Dr. \\ Sardjito Yogyakarta
}

Korespondensi: kakaratih@gmail.com

\begin{abstract}
ABSTRAK
Latar Belakang: Pemfigus vulgaris merupakan penyakit bula autoimun yang menyerang kulit, membran mukosa maupun keduanya, secara histologi ditandai dengan bula intraepidermal karena proses akantolisis pada lapisan suprabasal. Penatalaksanaan penyakit ini menggunakan kortikosteroid dosis tinggi dalam jangka waktu lama yang dapat berefek terhadap peningkatan kadar lemak darah, hipertensi, hiperglikemia, dan obesitas. Kadar total kolesterol dan LDL merupakan faktor resiko yang penting untuk terjadinya stroke baik stroke infark maupun perdarahan. Salah satu tampilan klinis dari stroke adalah Dizziness, yang dapat disebabkan karena gangguan peredaran darah otak. Keluhan ini dapat berupa "presyncopal light headedness", disequilibrium, dan vertigo. Setiap ada vertigo yang dihubungkan dengan gangguan peredaran darah otak maka lokasinya adalah daerah sirkulasi vertebrobasiler. Delapan puluh persen dari penyakit serebrovasculer adalah stroke iskemia, 20 persennya melibatkan sirkulasi vertebrobasiler. Vulgaris.

Tujuan: Deskripsi kasus sindroma vertigo sentral pada Pasien Pemfigus

Deskripsi Kasus: Perempuan 72 tahun, dikonsulkan dari bagian kulit karena keluhan pusing nggliyer, intensitas ringan-sedang, disertai gejala otonom ringan, diikuti kelemahan anggota gerak kanan onset akut. Pasien adalah penderita Pemfigus vulgaris, tegak sejak 1 tahun yang lalu, rutin mendapat terapi methyl prednisolon dosis tinggi dan obat kemoterapi cyclofosfamide. Pada pemeriksaan didapatkan status gizi obesitas, tekanan darah 102/70 $\mathrm{mmHg}$, nadi $80 \mathrm{x} /$ menit, pernafasan 20x/menit, suhu 36,8 $\mathrm{C}$, dan skala VVS 2. Dari pemeriksaan fisik didapatkan hemiparese dextra dan disequilibrium. Hasil pemeriksaan laboratorium menggambarkan kondisi dislipidemia dengan nilai Kolesterol 215 mg/dl, LDL 175 mg/dl. ASGM dan Siriraj stroke score mengarah pada lesi infark. Terapi: aspillet $1 \times 80 \mathrm{mg}$, flunarizin $1 \times 5 \mathrm{mg}$, valsartan $1 \times 40 \mathrm{mg}$, Inj siklofosfamide $500 \mathrm{mg} / 2 \mathrm{minggu}$, Inj Mesna $100 \mathrm{mg}$ (4 kali pemberian), Inj ondansetrone 1 ampul dan inj diphenhidramin 1 ampul (premedikasi siklofosfamide), Inj MP $125 \mathrm{mg} / \mathrm{minggu}$, Citirizin 1x10 mg, dan Imuran 2x500 mg. Setelah perawatan 3 hari, pasien pulang dengan perbaikan klinis.

Kesimpulan: pasien Pemfigus Vulgaris dengan stroke vertebrobasiler pada kasus ini menunjukkan perbaikan klinis setelah perawatan, selanjutnya pasien disarankan melakukan kontrol rutin.
\end{abstract}

Kata Kunci: sindroma vertigo sentral, stroke vertebrobasiler, pemfigus vulgaris 


\title{
CENTRAL VERTIGO SYNDROME, A VERTEBROBASILAR STROKE CLINICAL MANIFESTATION IN PEMPHIGUS VULGARIS
}

\author{
Ratih Kusumastuti ${ }^{1}$, Sri Sutarni ${ }^{2}$ \\ ${ }^{1}$ Neurology Resident Medical Faculty, Universitas Gadjah Mada/ Sardjito Central \\ Hospital Yogyakarta \\ 2Departement of Neurology Medical Faculty, Universitas Gadjah Mada/ Sardjito \\ Central Hospital Yogyakarta \\ Corespondence: kakaratih@gmail.com
}

\begin{abstract}
Background: Pemphigus Vulgaris is an autoimmune, intraepithelial, blistering disease affecting the skin and mucous membranes. Histologically, marked with intraepidermal bullae, produced from achantolysis in suprabasal layer. The management of the disease, the usage of high dose corticosteroid in a long time periode, increases blood fat level, hypertension, hyperglicemia, and obesity. Total cholesterol level and $L D L$ are known as an important risk factor in infarction stroke or hemorrhagic stroke. One of stroke clinical manifestation is Dizziness, which resulted from hemodynamic impairment in brain. It manifests as 'presyncopal light headedness', disequillibrium, and vertigo. Vertigo related to hemodynamic impairment in brain, usually was located in vertebrobasilar circulation. Eighty percent from cerebrovascular disease is ischemic stroke and twenty percent involve vertebrobasilar circulation.

Aim: To describe a central vertigo case in Pemphigus Vulgaris patient.

Case Description: 72 year-old female, consulted from Dermato-Venerology Department with chief complain Dizziness, low to moderate intensity, with mild otonomic manifestation, followed with weakness of right extremities, acute onset. Patient was diagnosed Pemphigus Vulgaris since one year ago and has routinely got high dose methyl prednisolone and cyclophosphamide chemotherapy. From examination obtained that she was obese, blood pressure 102/70 $\mathrm{mmHg}$, heart rate $80 x /$ minute, respiratory rate $20 x /$ minute, temperature $36,8^{\circ} \mathrm{C}$, and VVS 2 . From physical examination was obtained right hemiparese and disequillibrium. Laboratory examination describe a dyslipidemia condition with total cholesterol $215 \mathrm{mg} / \mathrm{dl}$, LDL 175 $\mathrm{mg} / \mathrm{dl}$. ASGM and Siriraj stroke score support an infarction stroke. Therapy: aspillet $1 \times 80$ $\mathrm{mg}$, flunarizin $1 \times 5 \mathrm{mg}$, valsartan $1 \times 40 \mathrm{mg}$, cyclophosphamide injection $500 \mathrm{mg} / 2$ weeks, Mesna injection $100 \mathrm{mg}$ (4 times gifts), ondansetrone injection 1 ampul and diphenhidramin injection 1 ampul (cyclophosphamide premedication), MP injection $125 \mathrm{mg} /$ week, Citirizin $1 \times 10 \mathrm{mg}$, and Imuran $2 \times 500 \mathrm{mg}$. After 3 days of treatment, she was discharged with clinical improvement.

Conclusion: a Pemphigus Vulgaris patient with vertebrobasilar stroke in this case, shows a clinical improvement after treatment, then patient advised for routine control.
\end{abstract}

Keywords: central vertigo syndrome, vertebrobasilar stroke, pemphigus vulgaris 


\section{LATAR BELAKANG}

Pemfigus vulgaris merupakan penyakit bula autoimun yang menyerang kulit, membran mukosa maupun keduanya, secara histologi ditandai dengan bula intraepidermal karena proses akantolisis pada lapisan suprabasal. Prevalensi pemfigus vulgaris 1-4 kasus per 100.000, dengan insidens 0,5-4 kasus per 1 juta orang per tahun; kejadian tertinggi di dunia terdapat di Amerika serikat dan Eropa. Dapat terjadi di seluruh kelompok usia, umumnya kelompok usia 50-60 tahun, sama antara pria dan wanita, dan diketahui berhubungan dengan human leucocyte antigen (HLA) DR4 dan DR6. ${ }^{1}$

Salah satu terapi medikamentosa pada penatalaksanaan penyakit ini adalah kortikosteroid dosis tinggi dalam jangka waktu lama. Hal ini tentunya meningkatkan resiko efek samping yang ditimbulkan oleh kortikosteroid. Salah satu efek samping glukokortikoid pada sistem endokrin dan metabolik yaitu peningkatan kadar lemak darah. ${ }^{2}$ Kadar total kolesterol dan LDL merupakan faktor resiko yang penting untuk terjadinya stroke baik stroke infark maupun perdarahan. ${ }^{3}$

Sebuah studi menunjukkan bahwa hiperlipidemiia pada pasien dengan terapi glukokortikoid dapat disebabkan oleh efek glukokortikoid yang menekan pelepasan ACTH. Pada studi ini, pemberian ACTH 3 minggu pada 9 pasien hiperlipidemia dengan penyakit ginjal yang mendapatkan terapi glukokortikoid, mengalami penurunan kadar trigliserida, kolesterol total, dan LDL serum 20$50 \%$ dan didapatkan peningkatan kadar HDL serum sebanyak 10-25\%. Disamping itu penggunaan glukokortikoid oral diketahui memiliki dampak sistemik cukup besar; termasuk hipertensi, hiper- glikemia, dan obesitas ${ }^{2}$ yang merupakan faktor resiko terjadinya stroke.

Salah satu tampilan klinis dari stroke adalah Dizziness, yang dapat disebabkan karena gangguan peredaran darah otak. Keluhan ini dapat berupa "presyncopal light headedness", disequilibrium, dan vertigo. Setiap vertigo yang dihubungkan dengan gangguan peredaran darah otak maka lokasinya adalah daerah sirkulasi vertebrobasiler. Delapan puluh persen penyakit serebrovasculer adalah stroke iskemia, 20 persennya melibatkan sirkulasi vertebrobasiler. Empat puluh tiga persen TIA vertebrobasiler menunjukkan gejala vertigo. 4

\section{LAPORAN KASUS}

Perempuan 72 tahun dikonsulkan dari bagian Kulit dengan keluhan pusing nggliyer, dirasakan sejak 5 hari sebelum masuk RS dengan intensitas ringan-sedang, kumat-kumatan, kadang disertai mual dan keringat dingin. Keluhan diikuti kelemahan ringan di anggota gerak sisi kanan sehingga agak tidak seimbang saat berjalan. Disangkal keluhan bicara pelo, perot, gangguan pendengaran/ telinga berdenging, kesemutan sesisi, gangguan daya ingat, gangguan BAB/ BAK.

Pasien adalah penderita Pemfigus vulgaris, tegak sejak 1 tahun yang lalu, rutin mendapat terapi methyl prednisolon dosis tinggi dan obat kemoterapi cyclofosfamide. Didapatkan riwayat keluhan serupa dengan tipe yang sama 8 bulan yang lalu dan didapatkan tekanan darah tinggi, dengan tekanan darah sistole 140. Disangkal adanya riwayat stroke, kencing manis, hipercholesterolemia, trauma kepala, tumor/ benjolan, infeksi telinga.

Saat dikonsulkan pasien tampak sakit ringan dengan kesadaran compos mentis. 
Didapatkan status gizi obesitas (BB $70 \mathrm{~kg}$, TB $150 \mathrm{~cm}$, BMI 31,11). Tekanan darah $102 / 70 \mathrm{mmHg}$, nadi 80x/menit, laju pernafasan $20 \mathrm{x} /$ menit, suhu $36,8^{\circ} \mathrm{C}$, dan skala VVS 2. Dari pemeriksaan fisik didapatkan kelemahan anggota gerak kanan dengan kekuatan 4+, peningkatan refleks fisiologis di empat ekstremitas, dan didapatkan refleks patologis positif di kedua ekstremitas atas. Pemeriksaan Nn cranialis, tonus, dan trofi otot dalam batas normal. Dari pemeriksaan khusus vertigo didapatkan tandem gait jatuh ke kanan, romberg dipertajam (mata tertutup) pasien jatuh ke kanan. Pemeriksaan nistagmus, dismetria, dan disdiadokokinesia, maupun Fukuda tidak didapatkan kelainan.

Pasien diassess dengan sindroma vertigo sentral cum hemiparese dextra onset akut et causa suspect vascular (stroke infark) pada pasien dengan Pemfigus Vulgaris. Pasien dilakukan pemeriksaan penunjang untuk menegakkan diagnosis dan evaluasi pengobatan antara lain pemeriksaan laboratorium, yang menggambarkan kondisi dislipidemia dengan nilai Kolesterol $215 \mathrm{mg} / \mathrm{dl}$, LDL 175 $\mathrm{mg} / \mathrm{dl}$, dan Trigliserida $136 \mathrm{mg} / \mathrm{dl}$. Hasil pemeriksaan darah rutin didapatkan kadar Leukosit darah $12,12 \times 10^{3} / \mathrm{uL}$, lain-lain dalam batas normal. Demikian pula dengan hasil pemeriksaan elektrolit dan kimia darah.

Pemeriksaan tambahan lainnya didapatkan hasil berupa defisit neurologis ringan dengan nilai NIHSS 2 dari poin total 42, ADL 0, IADL 0, Indeks Barthel 100. Skoring ASGM didapatkan suatu kriteria stroke infark dengan tidak didapatkannya penurunan kesadar-an, nyeri kepala, maupun tanda Babinski. Siriraj stroke score juga mengarah pada suatu stroke infark dengan poin -4 .

\section{PEMBAHASAN}

Pada laporan ini dideskripsikan suatu kasus stroke infark pada pasien Pemfigus Vulgaris dengan klinis berupa sindroma vertigo sentral cum hemiparese dextra onset akut. Kemungkinan letak lesi berada di area vascularisasi dari sistem vertebrobasiler.

Terapi yang diberikan pada pasien ini meliputi terapi non farmakologis berupa head up $30^{\circ}$, diet rendah garam dan rendah lemak, serta terapi farmakologi menggunakan Infus $\mathrm{NaCl}$ 0,9\% 16 tpm, aspillet $1 \times 80 \mathrm{mg}$, flunarizin $1 \times 5 \mathrm{mg}$, valsartan $1 \times 40 \mathrm{mg}$. Terapi lain terkait Pemfigus Vulgaris dari TS Kulit berupa Inj siklofosfamide $500 \mathrm{mg} / 2 \mathrm{minggu}$, Inj Mesna $100 \mathrm{mg}$ (4 kali pemberian), Inj ondansetrone 1 ampul (premedikasi siklofosfamide), Inj diphenhidramin 1 ampul (premedikasi siklofosfamide), Inj MP $125 \mathrm{mg} / \mathrm{minggu}$, Citirizin 1x10 $\mathrm{mg}$, dan Imuran 2x500 mg.

Vertigo merupakan suatu ilusi gerakan, biasanya berupa sensasi berputar yang akan meningkat dengan perubahan posisi kepala. Penyebab vertigo terbanyak adalah Benign Paroxysmal Positional Vertigo (BPPV), neuritis akut atau labirintitis, Meniere's disease, migraine serta reaksi ansietas. Cukup banyak penyebab vertigo baik vertigo tipe perifer, sentral atau tipe campuran. Bed side examination dapat mengarahkan diagnosis tipe vertigo, apakah vertigo tipe sentral, perifer atau vertigo tipe campuran. ${ }^{4}$

Definisi vertigo adalah adanya sensasi gerakan atau rasa gerak dari tubuh atau lingkungan sekitarnya dengan gejala lain yang timbul terutama dari jaringan otonomik yang disebabkan gangguan alat keseimbangan tubuh. Dizziness lebih mencerminkan keluhan rasa gerakan yang umum, tidak spesifik, rasa goyah, kepala ringan dan perasaan yang sulit dilukiskan oleh penderita 
sendiri. Giddiness berarti dizziness atau vertigo yang berlangsung singkat. 5

Vertigo bukan suatu gejala pusing saja, tetapi merupakan suatu kumpulan gejala atau satu sindroma yang terdiri dari gejala somatik (nistagmus, unstable), otonomik (pucat, peluh dingin, mual, muntah), dan pusing. Vertigo perlu dipahami karena merupakan keluhan nomer 3 paling sering dikemukakan oleh penderita yang datang ke praktek umum, bahkan pada orang tua sekitar 75 tahun, 50\% datang ke dokter dengan keluhan pusing.

Pemfigus vulgaris merupakan penyakit bula autoimun yang menyerang kulit, membran mukosa maupun keduanya. Secara histologi, penyakit ini ditandai dengan bula intraepidermal karena proses akantolisis pada lapisan suprabasal. ${ }^{7}$ Penyakit ini dimediasi oleh autoantibodi yang tersirkulasi dalam plasma yang menyerang sel keratinosit permukaan kulit. Merupakan penyakit yang berpotensi mengancam nyawa dan mempunyai tingkat mortalitas 5-15\%. Lesi primer dari pemfigus vulgaris berupa bula yang berisi cairan bening yang tumbuh dari permukaan kulit yang sehat atau dengan dasar kemerahan. ${ }^{8}$

Tatalaksana harus segera dilaksanakan segera setelah diagnosis meskipun lesi hanya sedikit, karena lesi akan cepat meluas dan jika tidak ditatalaksana dengan baik prognosisnya buruk. Tatalaksana pemfigus vulgaris dibagi dalam 3 fase yaitu fase kontrol, fase konsolidasi, dan fase maintenance. Fase kontrol adalah fase penyakit dapat dikontrol, terbukti dengan tidak terbentuknya lesi baru dan penyembuhan lesi yang sudah ada. Direkomendasikan kortikosteroid dosis tinggi, umumnya prednison 100-150 mg/hari secara sistemik, alternatif adalah dexamethason 100 $\mathrm{mg} /$ hari. Dosis harus di tappering off segera setelah lesi terkontrol. Selama terapi kortikosteroid dosis tinggi harus dipantau resiko diabetes, infeksi, hipertensi, gangguan jantung, dan paru. ${ }^{1}$

Kortikosteroid/ adrenokortikoid merupakan hormon yang berfungsi mengontrol sistem imunitas, pembentukan tulang, metabolisme, dan berperan sebagai respon terhadap stress. Hormon ini dibagi menjadi 2 yaitu glukokortikoid dan mineralokortikoid.

Glukokortikoid sudah lama dikenal karena efek kataboliknya, memecah persediaan energi tubuh untuk memenuhi kebutuhan metabolisme saat stress. Glukokortikoid dapat merangsang glikogenolisis (katalisa glikogen menjadi glukosa) dan glikoneogenolisis (katalisa lemak/ protein menjadi glukosa) sehingga kadar gula darah meningkat dan pembentukan glikogen di dalam hati dan jaringan menurun. Jika efek glukokortikoid meningkat maka akan menyebabkan gangguan distribusi lemak, sebagian lemak di bagian tubuh berkurang dan sebagian akan menumpuk pada bagian muka (moonface), tengkuk (buffalo hump), perut dan lengan. 9

\section{STROKE ISKEMIK}

Stroke adalah gangguan fungsional otak bersifat mendadak, baik berupa gangguan klinis fokal maupun global akibat gangguan fungsi otak yang berlangsung lebih dari 24 jam dan tidak ada penyebab lain selain vascular. Tidak termasuk disini gangguan peredaran darah sepintas, tumor otak, infeksi, atau sekunder akibat trauma. ${ }^{10}$

Prevalensi stroke di Amerika Serikat meliputi 69 stroke iskemik, $13 \%$ stroke perdarahan intraserebral, $6 \%$ perdarahan subarachnoid, dan $12 \%$ sisanya memiliki tipe yang tidak jelas. ${ }^{11}$ Prevalensi stroke iskemik di RSUP Dr Sardjito Jogjakarta pada 
tahun 2009 sebesar $70 \%$ dan stroke perdarahan $30 \% .{ }^{12}$

Stroke iskemik adalah stroke yang muncul akibat proses trombosis atau emboli yang mengenai satu atau lebih pembuluh darah di otak dan menyebabkan oklusi aliran darah. Oklusi ini nantinya menyebabkan aliran darah menurun atau hilang sama sekali diikuti dengan perubahan fungsional, biokimia, dan struktural yang menyebabkan kematian sel neuron yang irreversible. 10,13,14

Aliran darah ke otak pada keadaan normal berkisar 50mL/100 gr jaringan otak/menit. Aliran darah yang turun hingga $18 \mathrm{~mL} / 100 \mathrm{gr}$ jaringan otak/menit masih reversible karena struktur sel masih baik walaupun aktivitas listrik neuron terhenti. ${ }^{15}$ Penurunan aliran darah yang terus berlanjut akan menyebabkan kematian jaringan otak (infark). Prinsipnya, infark serebri ditimbulkan karena iskemik otak yang lama dan parah dengan perubahan fungsi dan struktur otak yang irreversibe. ${ }^{16}$

Seperti yang sudah disebutkan sebelumnya, bahwa salah satu tampilan klinis dari stroke adalah Dizziness, yang dapat disebabkan karena gangguan peredaran darah otak. Gejala klinis insufisiensi vertebrobasiler dapat dilihat secara klinis. TIA sirkulasi posterior muncul secara khas seperti vertigo dan dizziness. Untuk membantu penegakan diagnosis, disamping pemeriksaan klinis, diperlukan pemeriksaan penunjang berupa Imaging arteri. 4

Pemeriksaan penunjang adalah imaging otak, baik dengan CT scan atau MRI. pemeriksaan CT scan memiliki sensitivitas lebih dari 95\% jika digunakan untuk mengidentifikasi perdarahan intra atau ekstra-aksial dalam 24 jam pertama setelah onset. MRI lebih sensitif daripada CT scan dalam mengidentifikasi gambaran iskemia. MRI memiliki sensitifitas $97 \%$ dan spesifisitas 98\% ketika digunakan untuk menngidentifikasi oklusi vertebrobasiler. ${ }^{4}$

Penegakan diagnosis pada pasien ini hanya berdasarkan klinis, belum dilakukan pemeriksaan penunjang seperti CT scan sentrasi cerebellum dan atau MRI. Sebaiknya dilakukan pemeriksaan imaging lanjutan di samping pemerikssaan glukosa darah dan profil lipid untuk melihat faktor resiko. Pemeriksaan CT scan merupakan gold standar untuk membedakan adanya perdarahan atau tidak. Hal ini penting untuk pemberian antiplatelet segera mungkin begitu tidak ada tanda-tanda perdarahan.

Prognosis insufisiensi vertebrobasiler tergantung pada tanda neurologis, adanya kelainan arteri, lokasi dan perluasan infark, dan mekanisme iskemia. Emboli kardiak, kelainan arteri basilaris, dan kelainan banyak teritori intrakranial meningkatkan resiko hasil tidak memandang usia pasien dan faktor resiko yang mendasari. Penyakit oklusif arteri basilaris membawa resiko kecacatan dan kematian yang tinggi, serta identifikasi lesi harus secepat mungkin. ${ }^{4}$

\section{KESIMPULAN}

Kasus stroke vertebrobasiler dengan manifestasi klinis sindroma vertigo sentral pada pasien Pemfigus Vulgaris yang mendapatkan terapi kortikosteroid dosis tinggi dalam jangka waktu lama. Pada pemeriksaan didapatkan status gizi obesitas, tekanan darah $102 / 70 \mathrm{mmHg}$, nadi $80 \mathrm{x} / \mathrm{menit}$ laju pernafasan $20 \mathrm{x} /$ menit, suhu $36,8^{\circ} \mathrm{C}$, dan skala VVS 2. Dari pemeriksaan fisik didapatkan hemiparese dextra dan disequilibrium. Hasil pemeriksaan laboratorium menggambarkan kondisi dislipidemia dengan nilai Kolesterol 215 mg/dl, LDL 175 
mg/dl. ASGM dan siriraj stroke score mengarah pada lesi infark. Setelah mendapatkan terapi Aspillet 1x80 mg dan Flunarizin $1 \times 5 \mathrm{mg}$ pasien menunjukkan perbaikan klinis. Pasien dipulangkan setelah perawatan hari ketiga. Selanjutnya pasien disarankan untuk kontrol rutin di Poliklinik Saraf dan Kulit RSUP dr. Sardjito.

\section{DAFTAR PUSTAKA}

1. Bystryn J., Rudolph J. Pemphigus. Lancet. 2005;366(9479):61-73.

2. Moghadam S, Werth VP. Prevention and Treatment of Systemic Glucocorticoid Side Effects. Int $J$ Dermatol. 2010;49(3):239-248.

3. Grace Mary, K.J. Jacob, Arya Vijay Kumar et al. Role of Dyslipidemia in Stroke and Comparison of Lipid Profile in ischemic and Hemorrhagic Stroke- a case control study. International Journal of Advances in Medicine. 2016;3(3):694-698.

4. Sutarni S, Malueka RG, dan Gofir A. Bunga Rampai Vertigo. Yogyakarta : Gadjah Mada University Press. 2015.

5. Perdossi. Vertigo Patofisiologi, Diagnosis dan Terapi. Jansen Pharmaceuticals. 2000.

6. Greenberg, M.S. Handbook of Neurosurgery, $5^{\text {th }}$, Thieme, New York.

7. William V. Pemfigus Vulgaris : Diagnosis dan Tatalaksana. 2016; $C D K-247 /$ Vol. 43(12):905908. 2001.

8. Zeina, Bassam. Pemphigus Vulgaris Treatment\&Management. Medscape Dermatology. Accessed on September $28^{\text {th }}$, 2017 at http://www.emedicine. medscape.com/article/1064187treatment \#d6.htm

9. Peckett, Ashley J., David C. Wright, Michael C. Riddell. The Effects of Glucocorticoids on Adipose Tissue Lipid Metabolism. Metabolism Journal. 2011;60:1500-1510.

10. Jauch, Edward C. Ischemic Stroke. Medscape Emergency Medicine. Accessed on September 28 th, 2017 at http://www. emedicine.medscape.com/article / 1916852-overview\#a 1.htm

11. Wolfe, C., et al., Incidence and Case Fatality Rates of Stroke Subtypes in A Multiethnic Population: The South London Stroke Register. Journal of Neurology, Neurosurgery and Psychiatry. 2002. 72:211-216.

12. Setyopranoto, I. Oedem Otak pada Pasien Stroke Iskemik Akut. Badan Penerbit Fakultas Kedokteran Universitas Gadjah Mada Yogyakarta. 2012.

13. Adam R.D. Principles of Neurology. $7^{\text {th }}$ ed. 2001. Mc Graw Hill Inc. Singapore.

14. Bandera E.,Botteri M., Minelli C., et al. Cerebral Blood Flow Threshold of Ischemic Penumbra and Infark Core in Acute Ischemic Stroke. Stroke. 2006;37:13341339.

15. Lindsay KW, Bone I. Neurology and Neurosurgery Illustrated, 4th edition. Churchill Livingstone: United Kingdom. 2004.

16. Gofir, A. Klasifikasi Stroke dan Jenis Patologi Stroke. Dalam Manajemen Stroke Evidence Based Medicine. Pustaka Cendikia Press, Yogyakarta. 2009. 